\title{
A Sole-Candidate Election Involving a Non-Incumbent: The Unusual 2018 Mayoral Election in Makassar, Indonesia
}

\author{
Dewi Mayangsari ${ }^{1}$, Panji Anugrah Permana ${ }^{2}$ \\ \{de.mayangsari@gmail.com ${ }^{1}$, panji.anugrah@gmail.com ${ }^{2}$ \}
}

Student in the Department of Political Sciences, Universitas Indonesia, Depok, Indonesia ${ }^{1}$ Lecturer in the Department of Political Sciences, Universitas Indonesia, Depok, Indonesia ${ }^{2}$

\begin{abstract}
Political scientists have pointed out that the considerable power of incumbency has contributed to the high frequency of instances wherein incumbents running for reelection face no opposition. However, in Makasar, Indonesia, in 2018, something unusual happened: there was only one pair of candidates running for mayor and deputy mayor, and they were not incumbents. This paper analyzes the process that led to this unusual result, pointing out that the sole candidate election resulted because the incumbent was unable to solidify his political support in the face of strong, organized opposition. The incumbent mayor decided to run as an independent (without a party nomination) to avoid the party-led transition sought by the national elite opposition who wanted to prevent his nomination. However, he was ultimately barred from the election by a center-led transition resulting from legal challenges by the opposition forces, who successfully alleged that the mayor had committed violations while in office.
\end{abstract}

Keywords: Sole-candidate election, Incumbency, Elite competition, Makassar, Indonesia

\section{Introduction}

In local politics in Indonesia, elections with no competition are becoming increasingly common. As Table 1 shows, in the 2015 concurrent local election only 3 of 269 elections $(1.12 \%)$ had a sole pair of candidates running as a team; in 2017,9 of 101 were sole candidate (8.91\%); and in 2018, 16 of 171 elections (9.36\%) were sole candidate. In 25 of these 28 cases, at least one candidate in the pair was an incumbent; in two other cases, a relative of an incumbent was on the ticket. In only one case, in Makassar, were both members of the two-candidate team neither incumbents nor relatives of an incumbent.

This study focuses on the 2018 mayoral election in Makassar. Not only was it an outlier by having a non-incumbent pair of candidates, but it was also the only election that the sole candidate failed to win. Surprisingly, $53,23 \%$ of voters chose the empty box rather than the only pair of candidates running; because they failed to receive a majority of votes cast, they were not elected.

The 2018 election in Makassar had very different dynamics from the preceding elections. The 2008 mayoral campaign had seven pairs of candidates; in 2013, there were ten. These candidates represented various ethnic and professional backgrounds. In contrast, only two pairs of candidates registered in 2018, and after the disqualification of the incumbent mayor and his running mate, just one pair remained. 
Table 1. The recent development of sole-candidate local elections in Indonesia

\begin{tabular}{llll}
\hline \multicolumn{1}{c}{$\mathbf{2 0 1 5}$} & \multicolumn{1}{c}{$\mathbf{2 0 1 7}$} & \multicolumn{2}{c}{$\mathbf{2 0 1 8}$} \\
\hline $\begin{array}{l}\text { regions held } \\
\text { concurrent elections }\end{array}$ & $\begin{array}{l}101 \text { regions held } \\
\text { concurrent elections }\end{array}$ & 171 regions held concurrent elections \\
\hline $\begin{array}{l}3 \text { regions }(1.12 \%) \\
\text { sole-candidate elections }\end{array}$ & $\begin{array}{l}9 \text { regions }(8.91 \%) \text { had } \\
\text { sole-candidate } \\
\text { elections }\end{array}$ & $\begin{array}{l}16 \text { regions }(9.36 \%) \text { had sole- } \\
\text { candidate elections }\end{array}$ \\
\hline $\begin{array}{l}100 \% \text { of the sole- } \\
\text { candidate pairs had at }\end{array}$ & $\begin{array}{l}100 \% \text { of the sole- } \\
\text { candidate pairs had at } \\
\text { least one incumbent }\end{array}$ & $\begin{array}{l}13 \text { sole-candidate pairs had at least } \\
\text { one incumbent; } 2 \text { had a relative of an } \\
\text { incumbent; } 1 \text { was a non-incumbent }\end{array}$ \\
\hline $\begin{array}{l}100 \% \text { won by the sole } \\
\text { candidate }\end{array}$ & $\begin{array}{l}100 \% \text { won by the sole } \\
\text { candidate }\end{array}$ & $\begin{array}{l}15 \text { won by the sole candidate; } \\
\text { won by the empty box (no } \\
\text { candidate) }\end{array}$ \\
\hline
\end{tabular}

Competition between incumbents and other elites has been commonplace in Makassar. The incumbent mayor, Mohammad Ramdhan Pomanto, was a strong candidate who received support from the local branches of many political parties but then ended up registering independently (without a party nomination). The deputy mayor, Syamsu Rizal, did not register for the election due to facing the same legal challenges (described below) as the mayor. Neither the incumbent mayor nor the deputy mayor, ultimately obtained official party recommendations, which should be issued by the central board of parties. Munafri Arifuddin and Andi Rachmatika Dewi, the challengers, received support from a large coalition of ten political parties. Lay, Hanif, Ridwan, and Rohman (2017) refer to this situation as a pre-election elite competition, based on their examination of sole candidate elections in Pati and Jayapura in 2017. The pre-election elite competition in Pati was resolved by a sort of win-win solution, whereas the dynamics in Jayapura were more akin to a zero-sum game [1]. In Makassar, the latter pattern prevailed but in a reverse form, as the incumbent was unable to defend himself against a non-incumbent pair of candidates.

The incumbent mayor, Pomanto (popularly known as Danny), who had held office since 2014, teamed with Indira Mulyasari Paramastuti in 2018 to face the aforementioned Munafri Arifuddin and Andi Rachmatika Dewi (who campaigned under the title of Appi-Cicu). Indira Mulyasari was a deputy chairwoman of the local parliament (DPRD) of Makassar before resigning when nominated to run for deputy mayor. Munafri Arifuddin was the director of a Makassar football club and had no prior political experience. He is a relative of vice president Jusuf Kalla and of a famous businessman named Aksa Mahmud. Rachmatika Dewi was a legislator in the provincial parliament and is a relative of former mayor Ilham Arief Sirajuddin. Neither Danny nor Munafri Arifuddin was a member of any political party, whereas both Indira Mulyasari and her rival Rachmatika Dewi were members of the same political party, NasDem.

This study takes advantage of the unusual events in Makassar to fill a research gap on solecandidate elections. Previous research has looked at elections in which incumbents or their relatives or close supporters maintained a grip on power. There has been no research on a situation where a sole-candidate election resulted from the incumbent's failure to maintain power in the face of strong opposition, as occurred in Makassar.

\section{Theoretical Framework}


Sole-candidate elections have been occurring in Indonesian local elections for various reasons, including legal factors, the electoral system, the political parties, and elite competition. The sole-candidate election in 2015 was caused by the legal aspect [2][3] in which the law had no well-prepared legal framework [4]. Based on research conducted in Blitar, Dhesinta (2017) argued that political parties were reluctant to compete on behalf of their members in a contested local race [5]. Romli (2018) determined that the factors leading to the emergence of solecandidate elections included the pragmatism of political parties, the failure of regeneration, and the expensive "political dowry" required to get a party ticket. Legal requirements to register, the nature of the electoral system, and the centralization of political parties have all affected the number of people running for mayor by forcing candidates to amass considerable resources to become nominated and elected [6]. Manan (2016) found that the sole-candidate elections that occurred in 2015 were due to the large influence of party elites at the central level in deciding on the nomination of candidates [7]. The political parties tend to be pragmatic in determining candidates, mostly through a careful survey of candidates' popularity and electability, as occurred in Pati [8]. This situation benefits incumbents because of the considerable advantages of incumbency, as shown in the cases of Jayapura, Pati, and Blitar [1][5][9], where the candidates in these local sole-candidate elections were incumbents or people closely connected to them. In the cases of Pati and Jayapura, the incumbents won pre-election elite competitions with two different mechanisms. Pati exhibited a scare-off effect in which the strength of the incumbent and his wealthy running mate dissuaded rival candidates and parties from mounting a challenge. In Jayapura, two other candidates wanted to run and even secured backing from local party branches, but their candidacies were disallowed as a result of legal challenges [1]. In Makassar, a zero-sum-game pre-election elite competition between the incumbent and his opposition emerged as in Jayapura.

The theory of boundary control, developed by Edward Gibson (2012), describes a serial elite competition that is relevant for analyzing the pre-election elite competition in Makassar. The battle for control of the local territory between local and national elites provokes perpetual conflict among them. This fundamental pattern of conflict causes both the local authority (the incumbent in this case) and the opposition to attempt various measures to expand their power. The local opposition elite seeks to expand the issue to the national level (nationalization), which is part of the goal of opening up the boundary, since political pressure from the national level is a potential catalyst for local change [10].

Two types of local change can be generated from the national elite level: a party-led transition or a center-led transition. A party-led transition is a local democratization that occurs by means of party competition. Its national protagonists are the leaders of national political parties, who ally with local opposition parties and invest resources at the local level to defeat the local incumbent. This electoral challenge is carried out within the existing local rules of the game. In contrast, the center-led transition mechanism is a transition initiated through intervention by national authorities (executive, judicial, or legislative). This intervention transforms the local rules of the game [10].

The nationalization of a local crisis is a strategic challenge for the local ruling elite, and in such a situation the incumbent seeks to reinforce his or her position by exercising so-called boundary-strengthening to protect local jurisdiction. The local incumbent engages in boundary control in three sites of political action-subnational arenas, national arenas, and the institutional links between them - using three strategies. The first strategy, parochialization of power, seeks to increase local hegemony. When national party institutionalization is weak, the parochialization of power could include strengthening institutional alternatives such as bureaucratic institutions at all levels in the region. The second strategy, nationalization of 
influence, refers to the pursuit of national strategies or political positions to affect national decisions that have local impact. This approach is indispensable to local boundary control, because national influence is extremely beneficial in the successful management of local politics. The third strategy is the monopolization of national-subnational linkages. This could include institutions established to regulate relations between local and national or subnational governments, institutions, or people who monitor activities and expenditures, as well as institutions that regulate representatives of local interests at the central level. Whatever the strategy, the goal of boundary control by local incumbents is always to limit outside involvement in local politics [10].

\section{Research Method}

This study applied a qualitative, single-unit case-study approach. Data were collected from both primary and secondary data sources. Primary data included institutional documentation and personal interviews, which were either unstructured or semi-structured and largely openended. The selection of informants was based on their availability, capability, and involvement in the election, so as to ensure that accurate, valid information would be obtained. Secondary data came from previously existing literature.

\section{Findings}

\subsection{Political party centralization as a way to achieve party-led transition}

Leaders of nine political parties declared their support for the team of incumbent mayor Ramdhan Pomanto and Indira Mulyasari on November 22, 2017. The parliamentary parties were PDIP, Gerindra, PKS, PPP, PAN, and PKPI; the non-parliamentary parties were Perindo, Berkarya, and Idaman. This declaration was made without any official party recommendations. The media reported that PAN had issued a recommendation, but the candidates had no formal recommendation letter in their possession [11]. Rachmatika Dewi responded to the so-called endorsement that it was merely personal in nature, and that until a written recommendation could be produced, the support claimed from the political parties was dubious and incomplete. Moreover, she noted, even a recommendation would not guarantee long-term political support because it could be revoked at any time [12].

Ramdhan Pomanto viewed the situation (local parties support without recommendation) as a political scenario carried out in an attempt to defeat his candidacy. This view was seconded by the heads of the Democrat Party [13] and the Golkar Party [14]. In contrast, the Bappilu (Badan Pemenangan Pemilu or "Party's Electoral Campaign Body") chairperson of the NasDem Party considered the vague endorsements as opportunity-seeking behavior in a situation of incumbent weakness [15]. The declaration without the central board's recommendation was caused by a difference of opinion between the central party leaders and the local branches. The local leaders of political parties who supported Pomanto did not receive a response from the central board, but the central board allowed the local leaders to declare their support for the incumbent. Pomanto suspected that this action was an effort to deceive him until the deadline for submission of the required identity cards for petition signatures to run as an independent candidate. Once the deadline passed, the political party could have issued 
recommendations of a challenger. In Gibson's theory, this action could be described as a partyled transition.

The apparently half-hearted support for or even resistance to Pomanto's nomination cannot be separated from his performance as mayor. Views of his leadership among local politicians were split. Although some local political elites considered him a bad mayor [14], others spoke favorably of him, citing his background as a technocrat [15]. Nevertheless, his previous work and his relative lack of communication skills led to widespread stigma as a bad politician, arousing negative sentiments among several local politicians who condemned him by adopting this principle for the upcoming campaign: "anyone other than the incumbent mayor" [14].

Pomanto's suspicions regarding the unusual scenario and the apparent diversion of political party support were ultimately proved true. The six parliamentary political parties that had initially backed him (PDIP, Gerindra, PKS, PPP, PAN, and PKPI) switched their support to the opposition. The head of the local election desk for Gerindra revealed that Munafri Arifuddin had never been registered and participated in the party's selection process [16]. Less than two weeks before the recommendation of Appi-Cicu was issued, the local spokesperson for Gerindra confirmed that the party remained supportive of Pomanto and Indira Mulyasari [17]. Conflict in the PPP's (Partai Persatuan Pembangunan, or Unity Development Party) central party office between Djan Faridz and Romahurmuziy led to an initial split in support, but the party finally issued a recommendation of Appi-Cicu. Munafri Arifuddin registered at the central board of the PDIP (Partai Demokrasi Indonesia Perjuangan, or Indonesian Democratic Party of Struggle). He did not register at the local level because the time for registration at the local and provincial levels had passed. PDIP issued its recommendation of the challengers one day before the time period for candidacy registration at the KPU (Komisi Pemilihan Umum, or General Election Commission) ended. The day before that, hundreds of PDIP members accompanied Ramdhan Pomanto and Indira Mulyasari as they registered at the KPU [18].

Munafri Arifuddin and Rachmatika Dewi ended up with the backing of a large coalition of political parties. Ten political parties that cumulatively held 43 of the 50 seats in Makassar's local parliament supported their candidacy. This number easily exceeded the required minimum of 10 seats occupied by supportive parties. The coalition consisted of Golkar ( 8 seats), NasDem (5 seats), Hanura (5 seats), Gerindra (5 seats), PPP ( 5 seats), PKS (5 seats), PDIP (4 seats), PAN (4 seats), PKPI (1 seat), and PBB (1 seat). The Democrat party, with 7 seats, was the only one that officially unsupported both pairs of candidates.

The strategizing of the Appi-Cicu campaign took place with broad involvement by other local elites. The former mayor, Ilham Arief Sirajuddin, played a main role in designating Appi$\mathrm{Cicu}$ as the team to challenge Pomanto, who had previously been his assistant and close friend [19]. Sirajuddin was a key player in the process, arranging intensive communication with Aksa Mahmud, Munafri Arifuddin's father-in-law and a business tycoon with extensive national networks. Many politicians suspected that Aksa Mahmud had influence in the party's decision to recommend Appi-Cicu as candidates, although such a claim would be difficult to prove [20].

\subsection{Registering independently as a boundary-strengthening action}

Lacking support from the political parties, Ramdhan Pomanto and Indira Mulyasari submitted the necessary documents to run as independent candidates on the last possible day, just a week after the ten local branches of political parties declared their spoken 
recommendation. Despite the very short time to declare as independents, the incumbent and his running mate submitted documents with more than twice the required number of signatures $(132,980$, whereas the minimum was 65,354$)$. This impressive achievement showed that the mayor was well prepared for this course of action. It would have been very difficult to collect hundreds of thousands of identity cards and process them according to the technical requirements within one week. The head of the KPU of South Sulawesi Province was convinced that the registration process as independents had probably been initiated more than one week earlier [21]. Moreover, Pomanto already had the idea of registering as an independent before the declaration occurred [13]. And through his volunteer organization, Pakabaji Community, he had been collecting a large number of identity cards since the beginning of 2017 [22].

The incumbent's registration as an independent candidate was a boundary-strengthening action taken to protect him and his running mate against the political parties' attempts to weaken his position. The strategy also represented a parochialization of power to resist the parties' attempt to gain political control. Registering independently was Danny's only remaining way to avoid an opposition party-led transition. Indira did not play any role in strengthening her team's position since she had no access to her only significant political resource - the NasDem Party — of which she was a member, but which had declared its support for Munafri Arifuddin and Rachmatika Dewi.

\subsection{The emergence of a sole-candidate election due to a center-led transition}

After combating the threat of a party-led transition, Ramdhan Pomanto and Indira Mulyasari then had to deal with a center-led transition effort based on legal challenges. The objections charged that Danny had committed violations while serving as mayor by distributing smartphones to the RT/RW (head of neighborhood and hamlets), employing temporary government workers, and using the tagline " $2 \mathrm{x}+\checkmark$ " (dua kali tambah baik, or twice is better), which was also used as a tagline by local government. Law 10 of 2016 prohibits incumbents running for election from transferring employees or using their authority in ways that are beneficial or detrimental to a particular candidate within six months before the date of the appointment of the candidate to run the election [23].

Appi-Cicu initiated a lawsuit challenging the KPU's decision to approve Ramdhan Pomanto and Indira Mulyasari as eligible candidates. The first accusation was submitted to the Panwaslu (Panitia Pengawas Pemilu, or Election Supervisory Committee) of Makassar City. The committee rejected the request, stating that the KPU's decree permitting the incumbent's candidacy was valid and binding. Munafri Arifuddin and Rachmatika Dewi appealed to the PTTUN (Pengadilan Tinggi Tata Usaha Negara, or State Administration High Court), which overturned the Panwaslu ruling and instructed the KPU to revoke its decision. If upheld, the PTTUN's judgment would remove the incumbent's team from the ballot. The KPU of Makassar in turn appealed to the MA (Mahkamah Agung or Supreme Court), but that court rejected the appeal.

The KPU of Makassar decided to follow the Supreme Court's order after consulting with the KPU's central board and the KPU of South Sulawesi Province. It disqualified Ramdhan Pomanto and Indira Mulyasari on April 27, 2018, thereby producing a sole-candidate, nonincumbent election. In this context, the KPU's decision (under legal obligation) can be viewed as a center-led transition. The decision-making process at the local level, however, cannot be separated from the influence of institutions at the central level, as the PTTUN, the Supreme Court, and the KPU's central board directly impacted the dynamics of this local election. However, this action cannot be clearly interpreted as evidence of the opposition's political and 
legal control. Gibson (2012) defines a center-led transition as an intervention by national elite opposition [30], whereas in this case there is no evidence that the coalition of national party elites backing Munafri Arifuddin and Rachmatika Dewi had any influence over the decisionmaking processes of the KPU, the PTTUN, or the Supreme Court.

\section{Conclusion}

An examination of this unusual campaign in Makassar has shown that the sole-candidate election emerged due to a combination of party-led and center-led transition efforts, in two stages. First, the opposition attempted a party-led transition by denying the incumbent and constructing a large coalition with the recommendation of ten parties. The incumbent's response to this challenge was to engage in boundary-strengthening by registering as an independent. The opposition then undertook a second challenge, seeking to achieve a center-led transition through legal action. The incumbent had no boundary-strengthening tools to defend against this challenge and was eventually removed from the election. The dynamics of this competition can be seen in Figure 1.

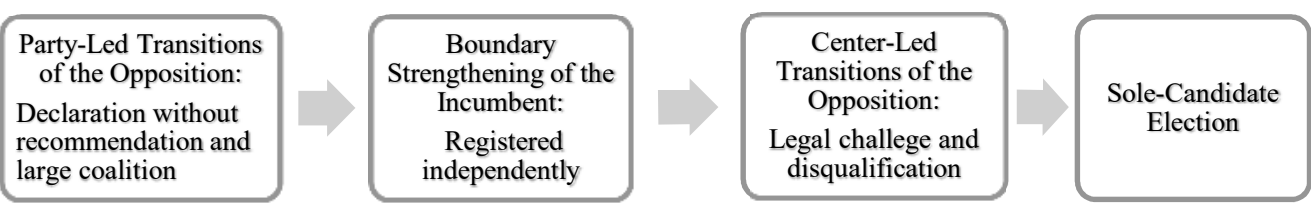

Figure 1. The dynamics of the contestation between the mayor and his opposition that resulted in a sole-candidate election.

\section{References}

[1] C. Lay, H. Hanif, and N. Rohman, "The Rise of Uncontested Elections in Indonesia: Case Studies of Pati and Jayapura," Contemp. Southeast Asia, pp. 427-448, 2017.

[2] R. Nazriyah, "Calon Tunggal Dalam Pilkada Serentak Tahun 2015 Terhadap Putusan Mahkamah Konstitusi No 100/PUU-XIII/2015," J. Konstitusi, vol. 13, no. 2, pp. 379-405.

[3] A. F. Gani Wardana, "Calon Tunggal Dalam Pemilihan Kepala Daerah Dan Wakil Kepala Daerah Perspektif Hukum Progresif," J. Fak. Huk. UII, vol. 23, no. 2, pp. 206-229.

[4] I. Rumesten, "Fenomena Calon Tunggal dalam Pesta Demokrasi," J. Konstitusi, vol. 13, no. 1, pp. $63-82,2016$.

[5] W. S. Dhesinta, "Calon Tunggal Dalam Pemilihan Umum Kepala Daerah dan Konsep Demokrasi: Analisa Terhadap Pemilihan Kepala Daerah Kabupaten Blitar 2015,” Jentera J. Huk., vol. 1, no. $1,2018$.

[6] L. Romli, "Pilkada Langsung, Calon Tunggal, dan Masa Depan Demokrasi Lokal," J. Penelit. Polit., vol. 15, no. 2, pp. 143-160, 2018

[7] F. Manan, "Pemilihan Kepala Daerah dengan Pasangan Calon Tunggal dalam Pilkada Serentak 2015," Conf. Pap., 2016.

[8] S. Yuristianti, "Fenomena Calon Tunggal Dalam Pemilihan Umum Kepala Daerah Kabupaten Pati 2017 (Studi Kasus: Sistem Rekrutmen Calon Oleh Partai Politik),” J. Polit. Gov. Stud., vol. 7, no. 2, pp. 61-70, 2018. 
[9] W. U. P. Danny, “ANALISIS REKRUTMEN DAN KADERISASI PARTAI POLITIK PADA FENOMENA CALON TUNGGAL PETAHANA: STUDI KASUS PILKADA KABUPATEN PATI 2017." Faculty of Social and Political Sciences, 2018.

[10] E. L. Gibson, Boundary control: Subnational authoritarianism in federal democracies. Cambridge University Press, 2013.

[11] A. Rianto, "(2019, Maret 12)," (Personal Interview).

[12] A. R. Dewi, “(2019, Maret 13)," (Personal Interview).

[13] A. R. Ali, “(2019, Maret 19)," (Personal Interview).

[14] F. M. Betta, “(2019, Maret 13)," (Personal Interview).

[15] M. David, “(2019, Maret 11)," (Personal Interview).

[16] A. Manrulu, "(2019, Maret 18)," (Personal Interview).

[17] S. Irawan, "2 Januari 2018, Gerindra Umumkan Usungan di PIlwali Makassar," 2017. [Online]. Available: http://makassar.tribunnews.com/2017/12/27/2-januari-2018-gerindra-umumkanusungan-di-pilwali-makassar.

[18] B. Machmud, “(2019, Maret 29)," (Personal Interview).

[19] I. A. Sirajuddin, “(2019, Maret 26)," (Personal Interview).

[20] "The informants asked their names not to be published."

[21] M. M. Attas, “(2019, Maret 25),” (Personal Interview).

[22] A. Ramadhan, "News: Pakabaji Community Dorong Danny Pimpin Makassar 2 Periode," 2017. [Online]. Available: https://makassar.terkini.id/pakabaji-community-dorong-danny-pimpinmakassar-2-periode.

[23] "Law 10 of 2016." 